Volume: 07, Issue: 06 "November-December 2021"

\title{
EFFECTS OF L-ARGININE ON FEED INTAKE, WATER CONSUMPTION, AND GROWTH PERFORMANCE OF SASSO, SHIKA BROWN, AND KUROILER PULLET STRAINS
}

\author{
${ }^{1}$ Ayoola J. Shoyombo, ${ }^{1}$ Victoria O. Olaoye, ${ }^{1}$ Gospel E. Onyeabor, ${ }^{2}$ Mustapha A. Popoola, \\ ${ }^{1}$ Olayinka O. Alabi, ${ }^{1 *}$ Ekemini M. Okon, ${ }^{3}$ Ahmed E. Jubril, ${ }^{2}$ Comfort I. Ukim, ${ }^{4}$ Umar D. Bunjah \\ ${ }^{1}$ Department of Animal Science, College of Agricultural Sciences, \\ Landmark University, P.M.B. 1001 Omu-Aran, Kwara State, Nigeria. \\ ${ }^{2}$ Research and Development, Office of the Executive Secretary, TETFUND, Abuja, Nigeria. \\ ${ }^{3}$ Department of Animal Science, University of Abuja, Abuja, Nigeria. \\ ${ }^{4}$ Agricultural Research Council, Abuja, Nigeria. \\ *Corresponding author
}

DOI: https://doi.org/10.51193/IJAER.2021.7607

Received: 27 Nov. 2021 / Accepted: 03 Dec. 2021 / Published: 23 Dec. 2021

\begin{abstract}
The poultry industry plays a significant role in meeting the food needs of the ever-increasing global human population. In Nigeria, poultry production has contributed to the social and economic advancement of farmers in many areas. However, the sector in Nigeria is faced with various challenges such as poor health and inadequate nutrition which affects growth. This study, therefore, investigates the effects of L-Arginine on feed consumption, water consumption, and growth performance of 3- pullet strains. A total of 297 12-week-old pullets comprising of 99 each for Sasso, Shika Brown, and Kuroiler strains were used in a 3 x 3 factorial trial design. Three levels of L-Arginine oral inclusion $(0.00 \mathrm{mg}, 500 \mathrm{mg}$, and $1000 \mathrm{mg} / 3000 \mathrm{ml}$ of water) were used for each treatment. All measured traits were not significantly $(p>0.05)$ affected by LArginine administration except for the Total Quantity of Active ingredient Consumed (TQAC) and Average Quantity of Active ingredient Consumed per bird (AQAC) that showed highly significant $(\mathrm{p}<0.0001)$ variations in a linear manner. All other traits were nominally higher with increasing levels of L-Arginine supplementation, except for feed intake. L-Arginine supplementation toleration and utilization were higher among the heavier strains (Kuroiler and Sasso) than the lighter strain (Shika brown).
\end{abstract}


International Journal of Agriculture and Environmental Research

ISSN: 2455-6939

Volume: 07, Issue: 06 "November-December 2021"

Keywords: Poultry nutrition; Supplementary Diets; Pullets; Feed Intake; Growth Performance

\section{INTRODUCTION}

The poultry industry is a major and important industry that significantly contributes to meeting the food needs of the growing human population (Kumar et al., 2021). In many parts of the world, poultry has been an important source of dietary protein to the teeming global population. In Nigeria, poultry production plays an essential role both economically and socially as a source of food and revenue for farmers in many areas. In the rural areas, poultry provides employment and social benefits ranging from the rearing of guinea fowl, chicken, etc to their supply chain (Shamsuddoha et al., 2015; Aswani et al., 2017).

Poultry, which is next only to ruminants as a source of animal protein in Nigeria, and accounts for almost $25 \%$ of local meat production. The total poultry population has been estimated at 120 million (Fayeye et al., 2006). However, there is consensus that about $90 \%$ of the figure derives from the local poultry stocks which are in turn composed of chickens (91\%), guinea fowl (4\%), ducks (3\%), turkeys, and others (2\%) (FLDPS/RIM, 1991).

Local chicken production, which is significant due to the various roles it serves, is an appropriate system for providing high-quality protein to the rapidly growing human population. In many parts of Nigeria, local chicken has been used on small scale as a source of monetary gains through the sale of eggs and live birds in both urban and rural marketplaces. Chickens are also utilized as high-quality animal nutrition in the form of eggs and meat for personal consumption, in traditional rituals, as a way of telling time, as gifts, and to strengthen marriages and friendships (Nwagu, 2002; Besbes, 2009; Marangoni et al., 2015).

Despite these advantages, poultry production in Nigeria is confronted with various challenges, including poor health, inadequate nutrition, inadequate housing, limited egg production, delayed growth, and mortality (Anosike et al., 2018). According to Nkukwana (2018), there appears to be a lack of information on current production challenges, possible interventions, and animal performance within production systems to properly exploit their potentials to improve productivity. This is especially true in developing countries, where local breeds are yet to be completely recognized and characterized, despite their ability to survive and produce in harsh circumstances with limited feed supply.

For instance, the Kuroiler chicken breed grows quicker and reaches maturity between 2 to 4 months old. The hens begin laying eggs at 3 months and continue for 2 years. A full-grown Kuroiler cock weights 4 to $5 \mathrm{~kg}$. Kuroiler chicks are also disease-resistant and may be easily treated with a combination of vitamins, feeds, and water (Alinaitwe et al., 2018: Rizvi and Teckchandany, 2018). Furthermore, many years of breeding and selection work at the National 
International Journal of Agriculture and Environmental Research

ISSN: 2455-6939

Volume: 07, Issue: 06 "November-December 2021"

Animal Production Research Institute (NAPRI) in Zaria resulted in the Shika-brown commercial layers with various desirable traits (Kallah, 1999). Compared to the aforementioned breeds, the Cobb Sasso is a slower-growing, colored chicken with robust health ideally suited to traditional, free-range, organic farming, and less intensive indoor production (Polson and Fanatico, 2002).

L-Arginine is an important amino acid in poultry. It is a precursor to different hormones, nitric oxides, proline, polyamines, creatine, and proteins. L-Arginine also functions in other important processes such as egg production, development of muscular mass, lipid metabolism, antioxidant defense, feathering, and growth (Khajali and Wideman, 2010; Al-Daraji et al., 2012; Fernandes et al., 2009; Fouad et al., 2012; Ruan et al., 2020).

In growing animals, the amino acid L-Arginine is required for optimum growth and nitrogen balance. Although most mature mammals can synthesize L-Arginine to meet their needs, chickens cannot. As a result, chickens rely entirely on dietary L-Arginine to meet their protein synthesis and other functional needs (Portocarero and Braun, 2021). According to Lewis (1997), birds are unable to produce any L-Arginine via the urea cycle, possibly due to a deficiency of carbamoyl phosphate synthetase I in mitochondria, and as a result, their dietary L-Arginine demand is higher than that of developing mammals. Dietary L-Arginine has a direct effect on metabolizable plasma L-Arginine (Kwak et al. 2001). The required magnitude is determined by several factors, including the age of the bird and feather coverage (Bequette, 2003), the source of dietary protein (Cuca and Jensen, 1990), dietary amino acid imbalances (Jahanian, 2009), and ambient temperatures and stressful conditions (Srinongkote et al., 2004).

There has been extensive information on how various nutrients affect pullets, there is limited information on the effects of L-Arginine on the growth performance of pullet strains. Previous studies only considered the chemical composition and physicochemical properties of meat from caponized roosters (Sánchez et al., 2005; Diaz et al., 2010) and the fatty acid profile of intramuscular fat in breast and drumstick (Rodrguez, 2010); thus, indicating the need for this study. Literature has also reported several works on lysine and methionine as limiting amino acids and their effects on various activities of poultry compared to L-Arginine. This study, therefore, aims to determine the effects of L-Arginine on feed consumption, water consumption, and growth performance 3- pullet strains.

\section{MATERIALS AND METHOD}

\subsection{Location of the Experiment}

The study was conducted at Landmark University Teaching and Research Farm, Omu Aran, Kwara State. 
International Journal of Agriculture and Environmental Research

ISSN: 2455-6939

Volume: 07, Issue: 06 "November-December 2021"

\subsection{Experimental Birds and Management}

A total of 297 12-week-old pullets comprising of 99 Sasso, Shika Brown, and Kuroiler strains respectively were used for the study. Before commencement of the experiment, the birds were vaccinated and medicated following the normal routine vaccination and medication regime.

\subsection{Experimental Design}

A $3 \times 3$ factorial trial was used thus, giving rise to 9 treatments. Each treatment was replicated thrice. The treatments with Sasso, Shika Brown, and Kuroiler strains had 11 birds each per replicate. There were three levels of L-Arginine oral inclusion $(0.00 \mathrm{mg}, 500 \mathrm{mg}$, and 1000 $\mathrm{mg} / 3000 \mathrm{ml}$ of water) for each treatment and replicates respectively. Data on growth performance (feed intake, water intake, and body weight) were then collected.

\subsection{Data Analysis}

The general linear model procedure of the Statistical Analysis System program (SAS, 2002) was used to test the effects of oral inclusion and strain. Significant means were separated using Turkey HSD multiple comparison tests (Turkey, 1953).

\section{RESULTS}

\subsection{Single effects of L-Arginine on growth, feed, and water consumption}

TABLE 1 describes the least square means (LSM), standard error $( \pm \mathrm{SE})$, and level of significance (LOS) of the single effect of L-Arginine administration at 0,500 , and $1000 \mathrm{mg}$ on total water consumed (TWC) (ml), the total quantity of active ingredient consumed (TQAC) (mg), the average quantity of water consumed per bird (AWC) (ml/bird), the average quantity of active ingredient consumed per bird (AQAC) (mg/bird), total feed consumed (TFC) (g), average feed consumed per bird (AFCB) (g/bird), feed conversion ratio (FER), the total body weight of bird per treatment (TBWT) $(\mathrm{Kg})$ and average body weight $(\mathrm{ABWT})(\mathrm{Kg})$.

All measured traits were not significantly ( $\mathrm{p}>0.05)$ affected by L-Arginine administration except for TQAC and AQAC that showed highly significant $(\mathrm{p}<0.0001)$ variations in a linear manner. All other traits were nominally higher with increasing levels of L-Arginine supplementation, except for feed intake which was nominally higher at $0 \mathrm{mg}$ supplementation, dropped at $500 \mathrm{mg}$ level, and increased at $1000 \mathrm{mg}$ level. 
International Journal of Agriculture and Environmental Research

ISSN: 2455-6939

Volume: 07, Issue: 06 "November-December 2021"

Table 1: Single effects of L-Arginine on growth, feed, and water consumption

\begin{tabular}{llllll}
\hline L-Arginine & $\mathbf{0 . 0 0 m g}$ & $\mathbf{5 0 0 m g}$ & $\mathbf{1 0 0 0 m g}$ & SEM & LOS \\
\hline *TWC (ml) & $16578.44 \pm 312.55$ & $16393.87 \pm 322.04$ & $16782.71 \pm 324.15$ & 1210.48 & NS \\
TQAC (mg) & $0.00^{\mathrm{c}} \pm 96.17$ & $2920.99^{\mathrm{b}} \pm 99.09$ & $5370.75^{\mathrm{a}} \pm 99.74$ & 372.46 & $* * *$ \\
$\begin{array}{l}\text { AWC } \\
\text { (ml/bird) }\end{array}$ & $1507.13 \pm 307.98$ & $1490.45 \pm 317.34$ & $2125.40 \pm 319.42$ & 1192.81 & NS \\
$\begin{array}{l}\text { AQAC } \\
\text { (mg/bird) }\end{array}$ & $0.00^{\mathrm{c}} \pm 8.68$ & $265.54^{\mathrm{b}} \pm 8.94$ & $486.88^{\mathrm{a}} \pm 9.00$ & 33.61 & $* * *$ \\
TFC (g) & $9447.69 \pm 78.47$ & $9154.38 \pm 80.85$ & $9416.84 \pm 81.38$ & 303.91 & NS \\
AFCB (g/bird) & $858.88 \pm 7.13$ & $832.18 \pm 7.35$ & $856.04 \pm 7.40$ & 27.62 & NS \\
FER & $1.93 \pm 0.27$ & $2.01 \pm 0.28$ & $2.01 \pm 0.27$ & 0.38 & NS \\
TBWT (Kg) & $17.88 \pm 0.28$ & $17.50 \pm 0.28$ & $18.38 \pm 0.28$ & 1.08 & NS \\
ABWT (Kg) & $1.66 \pm 0.14$ & $1.67 \pm 0.14$ & $1.72 \pm 0.14$ & 0.53 & NS \\
\hline abc means differ significanty (p<0.0001) across tratm & & & & \\
\hline
\end{tabular}

${ }^{\text {abc }}$ means differ significantly $(\mathbf{p}<0.0001)$ across treatment levels. NS: not significant

* total water consumed (TWC) (ml), the total quantity of active ingredient consumed (TQAC) (mg), the average quantity of water consumed per bird (AWC) (ml/bird), the average quantity of active ingredient consumed per bird (AQAC) (mg/bird), total feed consumed (TFC) (g), average feed consumed per bird (AFCB) (g/bird), feed conversion ratio (FER), total body weight of bird per treatment (TBWT) (Kg) and average body weight (ABWT) $(\mathrm{Kg})$.

\subsection{Single effects of breeds on growth, feed, and water consumption}

In TABLE 2, the single effect of breed on growth, water, and feed consumption are described. All traits except for ABWT and FER differed significantly ( $<<0.05)$. TWC, the quantity of active ingredient consumed and body weight were significantly higher with the Kuroiler followed by the Sasso and the Shika brown respectively, while higher feed intake was observed in the Sasso and the lowest intake in the Shika brown. 
International Journal of Agriculture and Environmental Research

ISSN: 2455-6939

Volume: 07, Issue: 06 "November-December 2021"

Table 2: Single effects of breeds on growth, feed, and water consumption

\begin{tabular}{llllll}
\hline Breeds & Shika brown & Kuroiler & Sasso & SEM & LOS \\
\hline $\begin{array}{l}\text { TWC } \\
(\mathrm{ml})\end{array}$ & $12141.19^{\mathrm{b}} \pm 325.31$ & $19099.82^{\mathrm{a}} \pm 313.01$ & $18514.01^{\mathrm{a}} \pm 320.42$ & 1210.48 & $*$ \\
$\begin{array}{l}\text { TQAC } \\
(\mathrm{mg})\end{array}$ & $2143.07^{\mathrm{b}} \pm 100.09$ & $3158.30^{\mathrm{a}} \pm 96.31$ & $2990.37^{\mathrm{a}} \pm 98.59$ & 372.46 & $*$ \\
$\begin{array}{l}\text { AWC } \\
(\mathrm{ml} / \mathrm{bird})\end{array}$ & $1103.75^{\mathrm{b}} \pm 320.56$ & $1736.48^{\mathrm{ab}} \pm 308.44$ & $2282.76^{\mathrm{a}} \pm 315.44$ & 1192.81 & $*$ \\
$\begin{array}{l}\text { AQAC } \\
(\mathrm{mg} / \mathrm{bird})\end{array}$ & $194.82^{\mathrm{b}} \pm 9.03$ & $287.12^{\mathrm{a}} \pm 8.69$ & $270.49^{\mathrm{a}} \pm 8.90$ & 33.61 & $* *$ \\
TFC $(\mathrm{g})$ & $8757.89^{\mathrm{b}} \pm 81.67$ & $9611.78^{\mathrm{a}} \pm 78.58$ & $9649.23^{\mathrm{a}} \pm 80.45$ & 303.91 & $*$ \\
$\begin{array}{l}\text { AFCB } \\
(\mathrm{g} / \mathrm{bird})\end{array}$ & $796.17^{\mathrm{b}} \pm 7.42$ & $873.75^{\mathrm{a}} \pm 7.14$ & $877.17^{\mathrm{a}} \pm 7.31$ & 27.62 & $*$ \\
FER & $1.72 \pm 0.27$ & $2.19 \pm 0.28$ & $2.02 \pm 0.27$ & 0.38 & NS \\
$\begin{array}{l}\text { TBWT } \\
(\text { Kg })\end{array}$ & $11.74^{\mathrm{b}} \pm 0.28$ & $21.80^{\mathrm{a}} \pm 0.28$ & $20.22^{\mathrm{a}} \pm 0.28$ & 1.08 & $*$ \\
$\begin{array}{l}\text { ABWT } \\
(\text { Kg })\end{array}$ & $1.37 \pm 0.14$ & $1.91 \pm 0.14$ & $1.77 \pm 0.14$ & 0.53 & NS \\
\hline
\end{tabular}

${ }^{\text {ab }}$ means differ significantly $(p<0.05 ; 0.01)$ across treatment levels. NS: not significant

See TABLE 1 for the definition of abbreviations

\subsection{Interactive effect of $L$-Arginine and breed on growth, water, and feed intake}

TABLE 3 shows the results of the interaction of the two factors on growth, water, and feed consumption. All traits showed significant $(\mathrm{p}<0.05)$ differences in means across the TABLE except FER. The highest TWC and AWC were observed with the Kuroiler breeds placed under $500 \mathrm{mg}$ of L-Arginine supplementation followed by Sasso at $1000 \mathrm{mg}$, there was no clear pattern of interaction for water consumption. Active ingredient consumption increased as expected with an increasing dose of L-Arginine. The trend of interaction showed that intake increased from Shika brown through Sasso to Kuroiler respectively. 
Feed consumption increased from 0 to 500mg and then declined at 1000mg for Shika brown and Kuroiler breeds while it linearly increased across L-Arginine levels in the Sasso breed. Bodyweight showed a linear and rising increase in the Kuroiler with an increase in L-Arginine level and there was no clear pattern for the other two breeds. 
International Journal of Agriculture and Environmental Research

ISSN: 2455-6939

Volume: 07, Issue: 06 "November-December 2021"

Table 3: Interactive effect of L-Arginine and breed on growth, water, and feed intake

\begin{tabular}{|c|c|c|c|c|c|c|c|c|c|c|c|}
\hline $\begin{array}{l}\text { L- } \\
\text { Arginine }\end{array}$ & 0.00mg & & & $500 \mathrm{mg}$ & & & $1000 \mathrm{mg}$ & & & SEM & LOS \\
\hline Breeds & $\begin{array}{l}\text { Shika } \\
\text { brown }\end{array}$ & Kuroiler & Sasso & $\begin{array}{l}\text { Shika } \\
\text { brown }\end{array}$ & Kuroiler & Sasso & $\begin{array}{l}\text { Shika } \\
\text { brown }\end{array}$ & Kuroiler & Sasso & & \\
\hline TWC (ml) & $\begin{array}{l}12856.13^{\mathrm{c}} \\
\pm 541.34\end{array}$ & $\begin{array}{l}19119.67^{\mathrm{ab}} \pm \\
541.34\end{array}$ & $\begin{array}{l}17759.53^{\mathrm{b}} \pm 5 \\
41.34\end{array}$ & $\begin{array}{l}11390.15^{\mathrm{c}} \pm 4 \\
68.82\end{array}$ & $\begin{array}{l}19187.93^{\mathrm{a}} \pm 5 \\
60.34\end{array}$ & $\begin{array}{l}18603.55^{\mathrm{ab}} \pm \\
632.15\end{array}$ & $\begin{array}{l}12177.30 \mathrm{c} \pm 6 \\
63.01\end{array}$ & $\begin{array}{l}18991.88^{\mathrm{ab}} \pm 52 \\
4.15\end{array}$ & $\begin{array}{l}19178.95^{\mathrm{a}} \pm 481 \\
00\end{array}$ & 698.87 & $*$ \\
\hline $\begin{array}{l}\text { TQAC } \\
(\mathrm{mg})\end{array}$ & $\begin{array}{l}0.00^{\mathrm{e}} \pm 166 \\
57\end{array}$ & $0.00^{\mathrm{e}} \pm 166.57$ & $0.00^{\mathrm{e}} \pm 166.57$ & $\begin{array}{l}2328.52^{\mathrm{d}} \pm 14 \\
4.25\end{array}$ & $\begin{array}{l}3257.46^{\mathrm{c}} \pm 17 \\
2.41\end{array}$ & $\begin{array}{l}3176.99^{c} \pm 19 \\
4.51\end{array}$ & $\begin{array}{l}4100.68^{b} \pm 20 \\
4.00\end{array}$ & $\begin{array}{l}6217.45^{\mathrm{a}} \pm 161 \\
28\end{array}$ & $\begin{array}{l}5794.11^{\mathrm{a}} \pm 148.0 \\
0\end{array}$ & 215.04 & $*$ \\
\hline $\begin{array}{l}\text { AWC } \\
\text { (ml/bird) }\end{array}$ & $\begin{array}{l}1168.74^{\mathrm{b}} \pm \\
553.44\end{array}$ & $\begin{array}{l}1738.15^{\mathrm{b}} \pm 55 \\
3.44\end{array}$ & $\begin{array}{l}1614.50^{\mathrm{b}} \pm 55 \\
3.44\end{array}$ & $\begin{array}{l}1035.47^{\mathrm{b}} \pm 46 \\
1.97\end{array}$ & $\begin{array}{l}1744.65^{\mathrm{b}} \pm 55 \\
2.17\end{array}$ & $\begin{array}{l}1691.23^{\mathrm{b}} \pm 62 \\
2.93\end{array}$ & $\begin{array}{l}1107.03 \mathrm{~b} \pm 65 \\
3.33\end{array}$ & $\begin{array}{l}1726.63^{\mathrm{b}} \pm 516 \\
50\end{array}$ & $\begin{array}{l}3542.54^{\mathrm{a}} \pm 473.9 \\
8\end{array}$ & 688.67 & $*$ \\
\hline $\begin{array}{l}\text { AQAC } \\
\text { (mg/bird) }\end{array}$ & $\begin{array}{l}0.00^{\mathrm{f}} \pm 15.0 \\
3\end{array}$ & $0.00^{f} \pm 15.03$ & $0.00^{f} \pm 15.03$ & $\begin{array}{l}211.68^{\mathrm{e}} \pm 13.0 \\
2\end{array}$ & $\begin{array}{l}296.13^{\mathrm{d}} \pm 15 . \\
56\end{array}$ & $\begin{array}{l}288.82^{\mathrm{d}} \pm 17 \\
55\end{array}$ & $\begin{array}{l}372.79 c \pm 18 \\
41\end{array}$ & $565.22^{\mathrm{a}} \pm 14.55$ & $522.64^{\mathrm{b}} \pm 13.36$ & 19.41 & $*$ \\
\hline $\mathrm{TFC}(\mathrm{g})$ & $\begin{array}{l}8982.79^{c} \pm \\
135.91\end{array}$ & $\begin{array}{l}9752.91^{\mathrm{a}} \pm 13 \\
5.91\end{array}$ & $\begin{array}{l}9607.38^{\mathrm{ab}} \pm 1 \\
35.91\end{array}$ & $\begin{array}{l}8519.26^{\mathrm{d}} \pm 11 \\
7.70\end{array}$ & $\begin{array}{l}9326.68^{b} \pm 14 \\
0.68\end{array}$ & $\begin{array}{l}9617.19^{\mathrm{ab}} \pm 1 \\
58.71\end{array}$ & $\begin{array}{l}8771.63 \mathrm{~cd} \pm 1 \\
66.46\end{array}$ & $\begin{array}{l}9755.76^{\mathrm{a}} \pm 131 \\
60\end{array}$ & $\begin{array}{l}9723.11^{\mathrm{a}} \pm 120.7 \\
6\end{array}$ & 175.46 & $*$ \\
\hline $\begin{array}{l}\text { AFCB } \\
\text { (g/bird) }\end{array}$ & $\begin{array}{l}816.62^{\mathrm{ab}} \pm 1 \\
2.35\end{array}$ & $\begin{array}{l}886.63^{\mathrm{a}} \pm 12.3 \\
5\end{array}$ & $\begin{array}{l}873.40^{\mathrm{a}} \pm 12.3 \\
5\end{array}$ & $\begin{array}{l}774.48^{c} \pm 10.7 \\
0\end{array}$ & $\begin{array}{l}847.82^{\mathrm{ab}} \pm 12 \\
79\end{array}$ & $\begin{array}{l}874.23^{\mathrm{a}} \pm 14.4 \\
3\end{array}$ & $\begin{array}{l}797.43^{c} \pm 15.1 \\
3\end{array}$ & $886.80^{\mathrm{a}} \pm 11.96$ & $883.88^{\mathrm{a}} \pm 10.98$ & 15.95 & $*$ \\
\hline FER & $1.57 \pm 0.22$ & $2.13 \pm 0.19$ & $2.07 \pm 0.26$ & $2.03 \pm 0.28$ & $2.23 \pm 0.32$ & $1.76 \pm 0.28$ & $1.58 \pm 0.21$ & $2.19 \pm 0.27$ & $2.22 \pm 0.34$ & 0.58 & NS \\
\hline $\begin{array}{l}\text { TBWT } \\
(\mathrm{Kg})\end{array}$ & $\begin{array}{l}12.26^{\mathrm{c}} \pm 0.4 \\
8\end{array}$ & $21.53^{\mathrm{a}} \pm 0.48$ & $19.87^{\mathrm{ab}} \pm 0.48$ & $11.11^{\mathrm{c}} \pm 0.42$ & $21.94^{\mathrm{a}} \pm 0.50$ & $19.46^{\mathrm{b}} \pm 0.56$ & $11.86^{\mathrm{c}} \pm 0.59$ & $21.95^{\mathrm{a}} \pm 0.47$ & $21.34^{\mathrm{a}} \pm 0.43$ & 0.62 & $*$ \\
\hline $\begin{array}{l}\text { ABWT } \\
(\mathrm{Kg})\end{array}$ & $1.28^{\mathrm{b}} \pm 0.24$ & $1.89^{\mathrm{a}} \pm 0.24$ & $1.81^{\mathrm{a}} \pm 0.24$ & $1.57^{\mathrm{b}} \pm 0.20$ & $1.89^{\mathrm{a}} \pm 0.24$ & $1.54^{\mathrm{b}} \pm 0.28$ & $1.26 b \pm 0.29$ & $1.94^{\mathrm{a}} \pm 0.23$ & $1.96^{\mathrm{a}} \pm 0.21$ & 0.30 & $*$ \\
\hline
\end{tabular}

See TABLE 1 for the definition of abbreviatio 
International Journal of Agriculture and Environmental Research

ISSN: 2455-6939

Volume: 07, Issue: 06 "November-December 2021"

\section{DISSCUSSION}

There is a scarcity of information on the impact of L-Arginine supplementation on water intake in laying birds making a comparison with the present study non-feasible. However, the highest water intake was at the $1000 \mathrm{mg}$ L-Arginine dosage, this may be connected with the fact that the dissolved solute impacts thirst and encourage further drinking in the experimental birds.

The lack of significant ( $p>0.05$ ) influence of L-Arginine supplementation on feed consumed as a group or averagely by individual birds observed in this study agreed with the findings of nonsignificance in feed intake from days 1-42days old broiler from the reports of Fernandes et al. (2014) and Murakami et al. (2012). The lack of significant impact of L-Arginine on FER however, were at variance with the reports of Fernandes et al. (2014) and Murakami et al. (2012) on broiler chickens but mean values obtained in this study were similar to the range of (1.541.99) reported by these authors. This may be due to differences in layers and broilers along with rearing conditions. The quantity of feed and water consumed may have more to do with the environment and genetics of the bird than the impact of L-Arginine ingestion as the birds were raised under optimal conditions.

Observed significant $(\mathrm{p}<0.05 ; 0.01)$ differences in feed and water intake and TBWT due to the single effect of breed and the interaction between L-Arginine levels and breeds are consistent with literature reports (Farooq et al., 2002; Adebambo, 2005; Ball et al., 2007; Lieboldt et al., 2015) about different strains and breeds having differing growth profile under different environments. The quantity of feed consumed in this study differed (603.81-704.76g) reported for four different strains of layers (Babcock, Nick-Chick, Hyline, and Hisex) (Farooq et al., 2002). From industrial standards, the Kuroiler and Sasso breeds are heavier breeds than the Shika brown breed hence, the better performance of these breeds compared to the Shika brown whose origin is domiciled in Nigeria. The obtained result also supports the report that Feed consumption is a variable phenomenon and is influenced by several factors such as the strain of the bird, the energy content of the diet, ambient temperature, density of birds in the shed, hygienic conditions, and rearing environment (Farooq et al., 2002). The knowledge of feed and water consumption and how it is affected by feed supplements such as amino acid (L-Arginine) and others will help suggest effective strategies for improving feed efficiency and utilization.

However, none of these breeds performed below recommended levels for the period of the study. The interaction of the factors of amino acid and breed was beneficial in this study with little or no feasible adverse effect. 
International Journal of Agriculture and Environmental Research

ISSN: 2455-6939

Volume: 07, Issue: 06 "November-December 2021"

\section{CONCLUSION}

Observed differences in this study on growth, feed, and water intake were more attributable to breed effect than amino acid supplementation. Hence, it is possible to select and breed any of these strains of birds for specific economic focus. L-Arginine supplementation toleration and utilization were higher among the heavier strains (Kuroiler and Sasso) than the lighter strain (Shika brown).

It is therefore recommended that further studies using higher and lower levels of L-Arginine supplementation on the strain and the growth rate, feed, and water consumption of Sasso, Shika brown and Kuroiler birds should be carried out.

\section{REFERENCES}

[1] Adebambo, O. A. (2005). Indigenous poultry breeds genetic improvement for meat and eggs. Proceedings of the 1st Nigerian International Poultry Summit (NIPS) Ota, Ogun State Nigeria, 1-8.

[2] Al-Daraji, H. J., Al-Mashadani, A. A., Al-Mashadani, W. K., Al-Hassani, A. S., \& Mirza, H. A. (2012). Effect of in ovo injection with L-arginine on productive and physiological traits of Japanese quail. South African Journal of Animal Science, 42(2), 139145..http://dx.doi.org/10.4314/sajas.v42i2.6

[3] Alinaitwe, J., Nalule, A. S., Okello, S., Nalubwama, S., \& Galukande, E. (2018). Nutritive and economic value of hydroponic barley fodder in kuroiler chicken diets. IOSR J. Agric. Vet. Sci, 12, 76-83.

[4] Anosike, F. U., Rekwot, G. Z., Owoshagba, O. B., Ahmed, S., \& Atiku, J. A. (2018). Challenges of poultry production in Nigeria: A review. Nigerian Journal of Animal Production, 45(1), 252-258.

[5] Aswani, P. B., Lichoti, J. K., Masanga, J., Oyier, P. A., Maina, S. G., Makanda, M., Moraa, G. K., Alakonya, A. E., Ngeiywa, K. J., \& Ommeh, S. C. (2017). Characterisation of the phenotypes associated with body growth and egg production in local chickens from three agro-climatic zones of Kenya. Livestock Research for Rural Development, 29(32), 1-10. Retrieved on 6th August, 2021 from http://www.lrrd.org/lrrd29/2/aswa29032.htm

[6] Ball, R. O., Urschel, K. L., \& Pencharz, P. B. (2007). Nutritional consequences of interspecies differences in arginine and lysine metabolism. The Journal of Nutrition, 137(6), 1626S-1641S.

[7] Bequette B. J.(2003). Amino acid metabolism in animals, In: Amino Acids in Animal Nutrition (D'Mello JPF ed.). Vol.2. pp.87-101. CABI Publishing. Wallingford.

[8] Besbes, B. (2009). Genotype evaluation and breeding of poultry for performance under sub-optimal village conditions. World's Poultry Science Journal, 65(2), 260-271. 
International Journal of Agriculture and Environmental Research

ISSN: 2455-6939

Volume: 07, Issue: 06 "November-December 2021"

[9] Cuca, G. M., \& Jensen, L. S. (1990). Arginine requirement of starting broiler chicks. Poultry Science, 69(8), 1377-1382.

[10] Díaz, O., Rodríguez, L., Salvador, A. T., \& García, A. C. (2010). Chemical composition and physico-chemical properties of meat from capons as affected by breed and age. Spanish Journal of Agricultural Research, (1), 91-99.

[11] Farooq, M., Mian, M. A., Durrani, F. R., \& Syed, M. (2002). Feed consumption and efficiency of feed utilization by egg type layers for egg production. Livestock Research for Rural Development, 14(1).

[12] Fayeye, T. R., Ayorinde, K. L., Ojo, V., \& Adesina, O. M. (2006). Frequency and influence of some major genes on body weight and body size parameters of Nigerian local chickens. Livestock research for rural development, 18(3), 37.

[13] FDLPS/RIM (1991). Nigerian National Livestock Survey Report. Federal Department of Livestock and Pest Control Services, Abuja, Nigeria.

[14] Fernandes, J. I. M., Murakami, A. E., de Souza, L. M. G., Ospina-Rojas, I. C., \& Rossi, R. M. (2014). Effect of arginine supplementation of broiler breeder hens on progeny performance. Canadian Journal of Animal Science, 94(2), 313-321.

[15] Fernandes, J. I. M., Murakami, A. E., Martins, E. N., Sakamoto, M. I., \& Garcia, E. R. M. (2009). Effect of arginine on the development of the pectoralis muscle and the diameter and the protein: deoxyribonucleic acid rate of its skeletal myofibers in broilers. Poultry Science, 88(7), 1399-1406.

[16] Fouad, A. M., El-Senousey, H. K., Yang, X. J., \& Yao, J. H. (2012). Role of dietary Larginine in poultry production. International Journal of Poultry Science, 11(11), 718.

[17] Jahanian, R. (2009). Immunological responses as affected by dietary protein and arginine concentrations in starting broiler chicks. Poultry Science, 88(9), 1818-1824.

[18] Kallah, M. (1999). Shika brown CommercialLayers; Rearing Guide Handbook.134pp.

[19] Khajali, F., \& Wideman, R. F. (2010). Dietary arginine: metabolic, environmental, immunological and physiological interrelationships. World's Poultry Science Journal, 66(4), 751-766.

[20] Kumar, V., Sharma, N., Lakkaboyana, S. K., \& Maitra, S. S. (2021). Silver nanoparticles in poultry health: Applications and toxicokinetic effects. In Silver Nanomaterials for Agri-Food Applications (pp. 685-704). Elsevier.

[21] Kwak, H., Austic, R. E., \& Dietert, R. R. (2001). Arginine-genotype interactions and immune status. Nutrition Research, 21(7), 1035-1044.

[22] Lewis, P. D., Perry, G. C., Farmer, L. J., \& Patterson, R. L. S. (1997). Responses of two genotypes of chicken to the diets and stocking densities typical of UK and 'Label Rouge'production systems: I. Performance, behaviour and carcass composition. Meat Science, 45(4), 501-516. 
International Journal of Agriculture and Environmental Research

ISSN: 2455-6939

Volume: 07, Issue: 06 "November-December 2021"

[23] Lieboldt, M. A., Halle, I., Frahm, J., Schrader, L., Weigend, S., Preisinger, R., \& Dänicke, S. (2015). Effects of long-term graded L-arginine supply on growth development, egg laying and egg quality in four genetically diverse purebred layer lines. The Journal of Poultry Science, 0150067.

[24] Marangoni, F., Corsello, G., Cricelli, C., Ferrara, N., Ghiselli, A., Lucchin, L., \& Poli, A. (2015). Role of poultry meat in a balanced diet aimed at maintaining health and wellbeing: An Italian consensus document. Food \& nutrition research, 59(1), 27606.

[25] Murakami, A. E., Fernandes, J. I., Hernandes, L., \& Santos, T. C. (2012). Effects of starter diet supplementation with arginine on broiler production performance and on small intestine morphometry. Pesquisa Veterinária Brasileira, 32, 259-266.

[26] Nkukwana, T. T. (2018). Global poultry production: Current impact and future outlook on the South African poultry industry. South African Journal of Animal Science, 48(5), 869-884.

[27] Nwagu, B. I. (2002). Production and Management of indigenous poultry species. In $A$ Training Manual in National Training Workshop on Poultry Production in Nigerian National Animal Production Research Institute, Shika, Zaria (pp. 10-26).

[28] Polson, S., \& Fanatico, A. (2002). Which bird shall Iraise?. Genetic Options for Pastured Poultry Producers: Meat-type Chickens and Turkeys.

[29] Portocarero, N., \& Braun, U. (2021). The physiological role of guanidinoacetic acid and its relationship with arginine in broiler chickens. Poultry Science, 101203.

[30] Rizvi, S., \& Teckchandany, S. (2018). Keggfarms Pvt. Ltd: a social enterprise and a way of life. Emerald Emerging Markets Case Studies.

[31] Rodriguez, L. (2010). Efectos de la raza, edad de sacrifico y alimentación en los parámetros de calidad de la canal y carne del capón de Villaba. Doctoral Thesis.

[32] Ruan, D., Fouad, A. M., Fan, Q. L., Huo, X. H., Kuang, Z. X., Wang, H., ... \& Jiang, S. Q. (2020). Dietary L-arginine supplementation enhances growth performance, intestinal antioxidative capacity, immunity and modulates gut microbiota in yellow-feathered chickens. Poultry science, 99(12), 6935-6945.

[33] Sánchez, L., De La Calle, B., Iglesias, A., \& Sánchez, B. (2005). Utilización de estirpes autóctonas para la producción del pollo Label. Archivos de zootecnia, 54(206-207), 491496.

[34] Shamsuddoha, M., Quaddus, M., \& Klass, D. (2015). Sustainable poultry production process to mitigate socio-economic challenge. Humanomics.

[35] Srinongkote, S., Smriga, M., \& Toride, Y. (2004). Diet supplied with L-lysine and L-arginine during chronic stress of high stock density normalizes growth of broilers. Animal Science Journal, 75(4), 339-343. 